\title{
GENETIC CHARACTERIZATION OF A BRANGUS-IBAGE CATTLE POPULATION - BIOCHEMICAL POLYMORPHISMS AND REPRODUCTIVE EFFICIENCY
}

\section{CARACTERIZAÇÃO GENÉTICA DE UMA POPULAÇÃO DE BOVINOS BRANGUS-IBAGÉ - POLIMORFISMOS BIOQUÍMICOS E EFICIÊNCIA REPRODUTIVA}

\author{
Luiz Ernani Henkes ${ }^{1}$ Lídia Gonzalez Papadopolis ${ }^{2}$ Clara Sabina Steigleder ${ }^{2}$ \\ José Carlos Ferrugem Moraes ${ }^{3}$ Tania de Azevedo Weimer ${ }^{4}$
}

\section{SUMMARY}

Biochemical techniques were used to investigate the genetic variability in a Brangus-Ibage population by determining allele frequencies of 18 blood protein systems: Hemogloin $\beta$ Chain (Hb), Albumin (Alb), Amylase (Am), Transferrin (Tf), Carbonic Anhydrase (CA), Ceruloplasmin (Cp), Malic Enzyme (ME), Diaphorase I and II (Dia I and Dia II), Slow Alpha 2 Macroglobulin (Ap), Acid Phosphatase (ACP), Esterase B and D (EstB and EstD), Phosphogluconate Dehydrogenase (PGD), Glucose-6-Phosphate Dehydrogenase (G-6-PD), GlucosePhosphate-Isomerase (GPI), Superoxide Dismutase (SOD) and Glyoxalase I (GLO). The percentage of polymorphic loci were estimated at 0.27, the mean number of alleles was 1.33 and the mean heterozygosity was 0.07. There was a good agreement between expected and observed heterozygosity values. The population was in agreement with Hardy-Weinberg expectations in all systems. Reproductive records allowed to estimate three parameters of reproductive efficiency: mean age at first calving (1152.15 \pm 166.60 days), mean calving interval (539.23 \pm 124.10 days) and mean weight at first calving $(391.02 \pm 37.59 \mathrm{~kg})$. No relationship was found between reproductive efficiency and genetic systems.

Key words: Brangus-Ibage cattle, genetic characterization, reproductive efficiency.

RESUMO

Técnicas bioquímicas foram utilizadas para determinar a variabilidade genética numa população de bovinos da raça Brangus-Ibagé com relação a 18 sistemas protéicos sangüíneos: Hemoglobina - Cadeia $\beta(\mathrm{Hb})$, Albumina (Alb), Amilase (Am), Transferrina (Tf), Anidrase Carbônica (CA), Ceruloplasmina (Cp), Enzima Málica (ME), Diaforase I and II (Dia I and Dia II), Macroglobulina $\alpha 2$ lenta (Ap), Fosfatase Ácida (ACP), Esterase $B$ and D (EstB and EstD), Fosfogliconato Desidrogenase (PGD), Glicose-6-Fosfato Desidrogenase (G-6-PD), GlicoseFosfato-Isomerase (GPI), Superóxido Dismutase (SOD) e Glioxalase I (GLO). O percentual de locos polimórficos foi estimado em 0,27, o número médio de alelos foi 1,33 e a heterozigosidade média foi de 0,07. Houve boa concordância entre a heterozigosidade média observada e a esperada. A população apresentou-se em equilíbrio de Hardy-Weinberg em todos os sistemas. Também foram determinados três parâmetros de eficiência reprodutiva: idade média ao primeiro parto $(1152,15 \pm 166,60$ dias $)$, intervalo médio entre partos $(539,23 \pm 124,10$ dias $)$ e peso médio da vaca ao primeiro parto $(391,02 \pm 37,59 \mathrm{~kg})$. Não se encontrou nenhuma associação entre os polimorfismos protéicos e os parâmetros de eficiência reprodutiva.

Palavras-chave: bovinos Brangus-Ibagé, caracterização genética, eficiência reprodutiva.

\section{INTRODUCTION}

The Brangus-Ibage is a composite beef cattle breed resulting from the crossing of Aberdeen Angus (ABG) and Nellore (NEL). This breed was

\footnotetext{
${ }^{1}$ Veterinarian, MSc., PhD. Student, Curso de Pós-graduação em Genética e Biologia Molecular, Universidade Federal do Rio Grande do Sul (UFRGS)

${ }^{2}$ Undergraduate student, Curso de Farmácia, UFRGS

${ }^{3}$ Veterinarian, MSc., PhD., EMBRAPA-CPPSUL.

${ }^{4}$ Geneticist, MSc., PhD., Curso de Pós-graduação em Genética e Biologia Molecular, UFRGS. E-mail: weimer@vortex.ufrgs.br. Author for correspondence.
} 
developed as a result of a search for a beef animal, which would retain the Nellore natural ability to thrive under adverse conditions in combination with the excellent Angus meat quality. Its composition was theoretically stabilized at 3/8 NEL and 5/8 ABG (CHAGAS et al., 1972). In Brazil, much of the early work in crossing Nellore and Aberdeen Angus cattle was done by the Brazilian Agricultural Research Corporation (EMBRAPA - CPPSUL). The studies involving such crosses back in 1945. At that time, similar crossings had been tested around the world, but in most of other countries, the Bos indicus breed was the Brahman instead of the Nellore.

Due to its hardiness under stress conditions, in the last decade the Brangus has become popular mainly in areas of high heat and humidity in Australia and America. Currently the Brangus-Ibage breed is undergoing a great expansion in Brazil, with more than 250 cattle breeders in the southern, southeastern and central western regions and more than 55,000 animals registered in a little more than two years of official registration (EMBRAPA, 1995).

Nowadays, the EMBRAPA, in association with Federal University of Pelotas (UFPEL), Federal University of Santa Maria (UFSM) and Federal University of Rio Grande do Sul (UFRGS) has initiated a program studing alternatives to improve reproductive efficiency in Brangus-Ibage. As part of this program, efforts are directed toward investigating the degree of genetic variation of the breed with the aim of characterize it and develop selection procedures to accomplish optimum use of both additive and nonadditive genetic variation. The genetic variability has been investigated in three levels: nuclear DNA, mitochondrial DNA and blood proteins. In this paper, it were investigated eighteen blood genetic systems and verified the possibility of associations among these genetic markers and reproductive performance.

\section{MATERIAL AND METHODS}

Blood samples were obtained from seventy five Brangus-Ibage cows by punction of jugular vein using ACD as anticoagulant and processed according to HENKES $\boldsymbol{e t}$ al. (1993). The genetic systems Hemoglobin $\beta$-Chain $(\mathrm{Hb})$, Albumin (Alb), Amylase (Am), Transferrin (Tf), Carbonic Anhydrase (CA), Ceruloplasmin (Cp), Malic Enzyme (ME), Diaphorase I and II (Dia I and Dia II), Slow Alpha 2 Macroglobulin (Ap), Acid
Phosphatase (ACP), Esterase B and D (EstB and EstD), Phosphogluconate Dehydrogenase (PGD), Glucose-6-Phosphate Dehydrogenase (G-6-PD), Glucose-Phosphate-Isomerase (GPI), Superoxide Dismutase (SOD) and Glyoxalase I (GLO) were carried out by horizontal starch gels electrophoresis according to HENKES et al. (1994). The Amylase was tested as described by GEBICKE-HÄRTER \& GELDERMANN (1977).

The genetic variability was estimated through the following parameters: gene frequencies for each marker, average number of alleles at each locus, expected heterozygosity for each locus and percentage of polymorphic loci (NEI, 1987). HardyWeinberg equilibrium was analyzed by exact tests using GENEPOP software (RAYMOND \& ROUSSET, 1995). Three estimates related to reproductive performance were obtained from EMBRAPA records: age at first calving (AFC expressed in days), mean weight at first calving (MWFC - expressed in $\mathrm{kg}$ ) and mean calving interval (CI - expressed in days). The first two estimates are related to growth rate and the other is an evaluation of reproductive performance. For this last measure only females with at least four calving records were considered. The relationship between reproduction data and genetic markers was analyzed by grouping the cows according to their protein phenotypes and calculating the average reproductive parameter for each one. The comparisons were performed through a non parametric statistic (since these variables do not have a normal distribution) of Kruskal-Wallis or Mann-Whitney U test using the SPSS $^{\circledR}$ for Windows ${ }^{\mathrm{TM}}$ Package.

\section{RESULTS AND DISCUSSION}

Thirteen proteins (Dia II, EstB, EstD, GPI, SOD, ME, ACP, CA, Ap, Cp, GLO, G-6-PD and $\mathrm{PGD}$ ) showed no variation and all individuals presented the same phenotype. The phenotype and gene frequencies for the five polymorphic loci $(\mathrm{Hb}$, Alb, Dia I, Tf and Am) are presented in table 1. There was a good agreement between expected and observed heterozygosity values and no departures from Hardy-Weinberg equilibrium were verified for any systems. The percentage of polymorphic loci was estimated as 0.27 , the mean number of alleles was 1.33 , and the mean heterozygosity was 0.07 .

The degree of polymorphism and the other variation parameters showed values lower than those obtained by other authors for different cattle 
Table 1 - Phenotypic and Gene Frequencies of Five Protein Systems in a Brangus-Ibage Herd $(n=75)$.

\begin{tabular}{|c|c|c|c|c|c|}
\hline System & \multicolumn{2}{|c|}{ Phenotype frequency } & Gene Frequency & ho & he \\
\hline $\mathrm{Hb}$ & $\begin{array}{l}\mathrm{Hb} A \mathrm{~A} \\
\mathrm{Hb} \mathrm{AB} \\
\mathrm{Hb} \mathrm{BB}\end{array}$ & $\begin{array}{l}0.00 \\
0.33 \\
0.67\end{array}$ & $\begin{array}{l}\boldsymbol{H} \boldsymbol{b}^{\boldsymbol{A}}=0.17 \\
\boldsymbol{H} \boldsymbol{b}^{\boldsymbol{B}}=0.83\end{array}$ & 0.33 & 0.28 \\
\hline Alb & $\begin{array}{l}\text { Alb FF } \\
\text { Alb FS } \\
\text { Alb SS }\end{array}$ & $\begin{array}{l}0.62 \\
0.29 \\
0.09\end{array}$ & $\begin{array}{l}\boldsymbol{A l b}^{\boldsymbol{F}}=0.66 \\
\boldsymbol{A l b}^{S}=0.34\end{array}$ & 0.50 & 0.46 \\
\hline DIA & $\begin{array}{l}\text { DIA FF } \\
\text { DIA FS } \\
\text { DIA SS }\end{array}$ & $\begin{array}{l}0.09 \\
0.30 \\
0.61\end{array}$ & $\begin{array}{l}\boldsymbol{D I A}^{\boldsymbol{F}}=0.76 \\
\boldsymbol{D I A}^{S}=0.24\end{array}$ & 0.30 & 0.37 \\
\hline $\mathrm{Tf}$ & $\begin{array}{l}\text { Tf AA } \\
\text { Tf AD } \\
\text { Tf AE } \\
\text { Tf DD } \\
\text { Tf DE } \\
\text { Tf EE }\end{array}$ & $\begin{array}{l}0.29 \\
0.31 \\
0.25 \\
0.08 \\
0.03 \\
0.04\end{array}$ & $\begin{array}{l}\boldsymbol{T \boldsymbol { f } ^ { \boldsymbol { A } }}=0.57 \\
\boldsymbol{T \boldsymbol { f } ^ { D }}=0.25 \\
\boldsymbol{T} \boldsymbol{f}^{\boldsymbol{E}}=0.18\end{array}$ & 0.58 & 0.59 \\
\hline Am & $\begin{array}{l}\mathrm{Am} B \mathrm{~B} \\
\mathrm{Am} \mathrm{BC} \\
\mathrm{Am} \mathrm{CC}\end{array}$ & $\begin{array}{l}0.46 \\
0.46 \\
0.08\end{array}$ & $\begin{array}{l}A \boldsymbol{m}^{B}=0.68 \\
\boldsymbol{A m}^{C}=0.32\end{array}$ & 0.53 & 0.50 \\
\hline
\end{tabular}

ho - Observed heterozygosity, he - Expected heterozigosyty, $\mathrm{n}=$ sample size.

breeds (TEJEDOR $\boldsymbol{e t} \boldsymbol{a l}$., 1986). These differences are probably due to the markers analysed. Comparing only the same loci investigated in both series, the present data are similar to those obtained by these authors. In order to investigate the degree of variability, it was decided to test a random sample of loci, independently of their variability to prevent biased upward estimates of variability. Therefore, the data are consistent with results obtained for other mammalian species in which a large random set of markers were investigated (LEWONTIN, 1974; HENKES et al., 1993, 1994).

In relation to the monomorphic systems found here, studies have also failed to find variation in bovine (BAKER \& MANWELL, 1980) and even in other ruminants (HENKES et al., 1993, 1994). The exception was CA that shows no variation in the present sample and has been related as polymorphic in many studies (TEJEDOR et al., 1986; PANEPUCCI, 1988), the slowest allele (CA S) ranging from 0.6 to 1.0 in taurine and Zebu cattle, this last one showing a third CA type that migrate slower than CA S and called CA Z (PENEDO et al., 1982). This result cohere with the frequencies observed in Aberdeen Angus, where CA S reaches values near 1.0 (SARTORE et al., 1969).
For $\mathrm{Hb}$, two alleles were found, the rarest one, $\mathrm{Hb} \mathrm{A}$ had a frequency of 0.17 . $\mathrm{Hb} \mathrm{A}$ had a higher prevalence in Bos taurus cattle (TEJEDOR $\boldsymbol{e t}$ al., 1986; BRAEND, 1972) and also in some Indian breeds (PRASAD et $\boldsymbol{a l} .$, 1983). The value obtained in the present study for $\mathrm{Hb} \mathrm{B}$ is the highest so far found in bovine and cannot be explained by a specific contribution of one of the founder breeds. Notwithstanding, this herd was never been selected in function of any $\mathrm{Hb}$ phenotype it cannot be exclude the possibility of selection effect if some $\mathrm{Hb}$ phenotype has a best fitness in that environment. In sheep, there are strong evidences of physiological differences among hemoglobin types (DAWSON \& EVANS, 1966, 1967; AGAR et al., 1972). The investigation of hemoglobin frequencies in other breeds reared in the same environment is important to elucidate this point. Another possibility is indirect selection if $\mathrm{Hb}$ is in linkage disequilibrium with some gene involved in any other trait that has been selected. The gene for globin $\beta$-chain was mapped at chromosome 15 in cattle and it is closely linked to the beta subunit of the follicle-stimulating hormone (FRIES, 1989) and the parathyroid hormone loci (FRIES et al., 1988; FOREMAN \& WOMACK, 1989) as well as in synteny with myogenic factor 3 (MYOD1), a muscle-specific gene (RYAN et al., 1997). These two last genes play an important role in muscular development and therefore the selection based on morphologic aspect applied to this herd could indirectly affect $\mathrm{Hb}$ genotype distribution.

The Alb, Tf, Am and Dia frequencies are within the range of variation observed in Zebu crossings (BORTOLOZZI, 1983; PANEPUCCI, 1988, 1989) and in European cattle (GAHNE $\boldsymbol{e t}$ al., 1977; BAKER \& MANWELL, 1980; TEJEDOR $\boldsymbol{e} t$ al., 1986). It was found no specific allele for this breed and the gene frequencies agreed with the historical composition of the herd with a higher percentage of Aberdeen Angus component. It is also possible that these animals' environment or the selection management applied to them favor Angus genotype. The mean age at first calving, calving intervals and weight at first calving in the total sample and within each protein phenotype are presented in table 2 . No differences in reproduction performance among the different genotypes were observed. Although it had been reported that transferrin polymorphisms affect fertility in dairy and beef cattle (ASHTON \& FALLON, 1962), these 
Table 2 - Productive traits averages in total sample and in relation to protein phenotypes in a Brangus-Ibage herd.

\begin{tabular}{|c|c|c|c|c|c|c|}
\hline Phenotype & $\operatorname{AFC}(\text { days })^{\mathrm{a}}$ & $\chi^{2}$ & $\mathrm{CI}$ (days) ${ }^{\mathrm{b}}$ & $\chi^{2}$ & MWFC & $\chi^{2}$ \\
\hline $\mathrm{Hb} \mathrm{AB}$ & $1126.80 \pm 43.29$ & $0,74^{\mathrm{d}}$ & $573.43 \pm 140.39$ & $0,45^{\mathrm{d}}$ & $337.60 \pm 41.12$ & $0,86^{4}$ \\
\hline $\mathrm{Hb} \mathrm{BB}$ & $1172.13 \pm 189.64$ & & $532.19 \pm 100.99$ & & $351.90 \pm 47.52$ & \\
\hline Alb FF & $1129.33 \pm 152.08$ & 1,27 & $517.82 \pm 123.43$ & 5,61 & $353.72 \pm 49.11$ & 0,25 \\
\hline Alb FS & $1164.04 \pm 180.41$ & & $538.73 \pm 102.75$ & & $349.56 \pm 43.47$ & \\
\hline Alb SS & $1193.83 \pm 178.43$ & & $651.72 \pm 150.22$ & & $347.83 \pm 53.99$ & \\
\hline DIA FF & $1204.50 \pm 358.50$ & 1,07 & $647.85 \pm 42.21$ & 3,28 & $347.44 \pm 56.65$ & 2,86 \\
\hline DIA FS & $1194.00 \pm 195.62$ & & $518.70 \pm 100.31$ & & $363.65 \pm 40.74$ & \\
\hline DIA SS & $1154.41 \pm 171.73$ & & $551.17 \pm 138.95$ & & $361.46 \pm 50.54$ & \\
\hline Tf AA & $1148.13 \pm 160.95$ & 3,50 & $535.57 \pm 160.62$ & 3,14 & $350.06 \pm 47.66$ & 6,66 \\
\hline $\mathrm{Tf} \mathrm{AD}$ & $1159.56 \pm 162.88$ & & $524.35 \pm 100.97$ & & $368.31 \pm 50.29$ & \\
\hline $\mathrm{Tf} \mathrm{AE}$ & $1156.24 \pm 184.67$ & & $551.17 \pm 138.95$ & & $334.35 \pm 44.31$ & \\
\hline Tf DD & $1205.00 \pm 212.16$ & & $511.58 \pm 69.86$ & & $362.75 \pm 29.95$ & \\
\hline Tf DE* & 1065 & & 521 & & & \\
\hline Tf EE* & 913 & & 469 & & & \\
\hline $\mathrm{Am}$ AA & $1142.61 \pm 155.56$ & 0,04 & $529.88 \pm 133.23$ & 5,47 & $393.87 \pm 41.81$ & 1,77 \\
\hline $\mathrm{Am} \mathrm{AB}$ & $1169.68 \pm 185.56$ & & $569.45 \pm 113.29$ & & $388.25 \pm 33.48$ & \\
\hline Am BB & $1197.00 \pm 53.03$ & & $435.67 \pm 74.10$ & & & \\
\hline Total sample & $1152.15 \pm 166.60$ & & $435.67 \pm 74.10$ & & $391.02 \pm 37.59$ & \\
\hline
\end{tabular}

${ }^{\mathrm{a}} \mathrm{AFC}=$ Mean age at first calving \pm standard deviation (days), ${ }^{\mathrm{b}} \mathrm{CI}=$ Mean calving intervals \pm standard deviation (days), ${ }^{\mathrm{C}} \mathrm{MWFC}=$ Mean Weight at first calving \pm standard deviation $(\mathrm{kg}){ }^{\mathrm{d}}$ $=\mathrm{Z}_{\text {calc }}{ }^{*}$ Since only one animal presented Tf DE and Tf EE genotypes, no standard deviation was estimated.

data did not lent support to this hypothesis. Most of reproduction traits have low heritability estimates $[\mathrm{AFC}=0.14 \pm 0.18, \mathrm{CI}=0.10 \pm 0.18$ (KOOTS et al. , 1994)]. However, due to their high coefficient of variation it is possible to have good annual rates of response to selection, even with low heritabilities (BRADFORD, 1985).

Despite the great amount of studies reporting blood polymorphism in dairy cattle (ROCHA et al., 1998) little is known regarding the genetic variation in beef cattle. Dairy cattle is commonly raised under intensive management and controlled environment, the reproductive records being taken more easily and with more confidence. Beef cattle, on the other hand, is generally raised free and under all environment challenges. Since reproduction is a multifatorial trait, any subtle genetic difference could be easily diluted by the environmental components.

Considering the lack of association verified amongst the genetic markers and reproductive parameters investigated at the present study, it can be concluded that to search for a suitable marker as a tool for marker assisted selection for reproductive efficiency a larger set of polymorphic markers to cover all genome should be necessary (WELLER et al, 1997). Therefore, it is important to expand the repertoire of known genetic marker loci in this breed in order to determine appropriate implementation strategies and cost-benefit ratios for using genetic markers in animal breeding.

\section{ACKNOWLEDGEMENTS}

Thanks are due to Empresa Brasileira de Pesquisa Agropecuária (EMBRAPA - CPPSUL) for the facilities provided.

This study was supported by the Programa Nacional de Núcleos de Excelência (PRONEX), Fundação de Amparo à Pesquisa do Estado do Rio Grande do Sul (FAPERGS), Financiadora de Estudos e Projetos (FINEP), Conselho Nacional de Pesquisa ( $\mathrm{CNPq})$ and Próreitorias de Pesquisa e de Pós-graduação da Universidade Federal do Rio Grande do Sul.

\section{REFERENCES}

AGAR, N.S., EVANS, J.V., ROBERTS, J. Red blood cell potassium and hemoglobin polymorphism in sheep: A Review. Anim Breed Abst, v.40, p.407-436, 1972.

ASHTON, G.C., FALLON, G.R. $\beta$-Globulin type, fertility and embryonic mortality in cattle. J Reprod Fertil, v.3, p.93$104,1962$.

BAKER, C.M., MANWELL, C. Chemical classification of cattle. 1. Breed groups. Anim Blood Grps Biochem Genet, v.11, p.127-50, 1980.

BRAEND, M. Studies on the relationships between cattle breeds in Africa, Asia and Europe: Evidence obtained by studies of blood groups and protein polymorphisms. World Rev Anim Prod, v.8, p.9-14, 1972.

BORTOLOZZI, J. Polimorfismo da transferrina sérica em bovinos da raça Canchim. Pesq Vet Bras, v.3, p.53-57, 1983.

BRADFORD, G.E. Selection for litter size. In: LAND, R.B., ROBINSON, D.W. Genetics of reproduction in sheep. London: Butterworths, 1985. Cap.1. p.3-17. 
CHAGAS, E.C., CAGGianO, F.P., GARCIA, J.T.C. Formação do 5/8 Angus - 3/8 Zebu, Pelotas, RS : Ministério da Agricultura, DNPA, 1972. 8p. (Circular Técnica n.57).

DAWSON, T., EVANS, J.V. Effect of hypoxia on oxygen transport in sheep with different haemoglobin types. Am J Phys, v.210, p.1021-1025, 1966.

DAWSON, T., EVANS, J.V. Effects of anaemia on oxygen transport in sheep with different hemoglobin types. Am J Exp Biol Med Sci, v.45, p.437-444, 1967.

EMBRAPA. Brangus-Ibage. http://www.cenargen.embrapa.br/ embrapa/ portfolio/producao/brangu.html, 1995

FOREMAN, M.E., WOMACK, J.E. Genetic and synteny mapping of parathyroid hormone and beta hemoglobin in cattle. Biochem Genet, v.27, p.541-550, 1989.

FRIES, R., HEDIGER, R., STRAZINGER, G. The loci for parathyroid hormone and beta-globin are closely linked and map to chromosome 15 in cattle. Genomics, v.3, n.4, p.302307, 1988.

FRIES, R. The gene for the beta subunit of the folliclestimulating hormone maps to bovine chromosome 15 . J Hered, v.80, p.401-403, 1989

GAHNE, B., JUNEJA, R.K., GROLMUS, J. Horizontal polyacrilamide gradient gel electrophoresis for the simultaneous phenotyping of transferrin, postransferin, albumin and postalbumin in the blood of cattle. Anim Blood Grps Biochem Genet, v.8, p.127-137, 1977.

GEBICKE-HÄRTER, P.J., GELDERMANN, H. Inheritance of Amylases in blood serum of cattle. Biochem Genet, v.15, p.59-73, 1977.

HENKES, L.E., WEIMER, T.A., FRANCO, M.H.L.P. et al. Genetic characterization of the "Crioula Lanada" sheep from southern Brazil. Rev Bras Genet, v.16, p.449-455, 1993.

HENKES, L.E., WEIMER, T.A., MORAES, J.C.F Genetic markers and fertility gene $\left(\mathrm{Fec}^{B}\right)$ in a 3/4/ Romney Marsh x 1/4 Merino Booroola flock. Small Rum Res, v.14, p.55-59, 1994.

KOOTS, K.R., GIBSON, J.P., SMITH, C. et al. Analyses of published genetic parameters estimates for beef production traits. 1. Heritability. Anim Breed Abst, v.62, p.309-338, 1994.
LEWONTIN, R.C. The genetic basis of evolutionary change. NY : Columbia Univ, 1974. 344p.

NEI, M. Molecular evolutionary genetics. NY : Columbia Univ, 1987. 512p.

PANEPUCCI, L. Carbonic anhydrase polymorphisms in Nellore, Canchim and in dairy crossbred cattle in Brazil. Rev Bras Genet, v.11, p. 873-880, 1988.

PANEPUCCI, L. A study of biochemical polymorphisms in European/Zebu dairy crossbred cattle and of their relationship with European and Zebu cattle. Rev Bras Genet, v.12, p.27$37,1989$.

PENEDO, M.C.T., MORTARI, N., MAGALHÃES, L.B Carbonic anhydrase polymorphism in Indian Zebu cattle. Anim Blood Grps Biochem Genet, v.13, p.141-143, 1982.

PRASAD, S.K., PANDEY, R.S., NAIR, K.G.S. et al. Genetics polymorphism of blood proteins. World Rev Anim Product, v.XIX, p.55-61, 1983.

RAYMOND, M., ROUSSET, F. GENEPOP (version 1.2), a population genetics software for exact tests and ecumenicism. J Hered, v.86, p.248-249, 1995.

ROCHA, J.L., SANDERS, J.O., CHERBONNIER, D.M. et al. Blood groups and milk type traits in dairy cattle: After forty years of research. J Dairy Sci, v.81, p.1663-1680, 1998.

RYAN, A.M., SCHELLING, C.P., WOMACK, J.E. $\boldsymbol{e t}$ al. Chromosomal assignment of six muscle-specific genes in cattle. Animal Genetics, v.28, p.84-87, 1997.

SARTORE G., STORMONT C., MORRIS B.G. et al. Multiple electrophoretic forms of carbonic anhydrase in red cells of domestic cattle (Bos taurus) and American buffalo (Bison bison). Genetics, v.61, p.823-31, 1969.

TEJEDOR, T., RODELlAR, C., ZARAGOSA, P. Analysis of genetic variation in cattle breeds using electrophoresis studies. Arch Zootec, v.35, p.225-237, 1986.

WELLER, J.L., SOLLER, M., KOROL, A.B. (Detection of quantitative trait loci an Marker-assisted selection - Course Notes and Abstracts. 24 August - 4 September, Jersusalem, Israel :Kibbutz Mitzpeh Rachel Guesthouse, 1997. 